\title{
Assessment of Nutri-Chemical Concentration Levels of Wastewater from Drains Adjacent Cement and Associated Factories in Port Harcourt, Nigeria
}

\author{
Iyama, William Azuka1, Okotume, Sylvester Chukwuemeka², Edori, Onisogen Simeon ${ }^{3}$ \\ ${ }^{1}$ Rivers State College of Health Science and Management Technology, Port Harcourt, Rivers State, Nigeria. \\ ${ }^{2}$ Department of Chemistry Education, Federal College of Education (Technical) Asaba, Delta State, Nigeria \\ ${ }^{3}$ Department of Chemistry, Ignatius Ajuru University of Education, Rumuolumeni, PMB 5047 Port Harcourt, \\ Rivers State, Nigeria
}

*Corresponding Authors: Onisogen Simeon, Department of Chemistry, Ignatius Ajuru University of Education, Rumuolumeni, PMB 5047 Port Harcourt, Rivers State, Nigeria

\begin{abstract}
This study was designed to ascertain the level of Nutri-chemical parameters from the drains adjacent the cement industry, gas tank farm and other associated activities in the Iwofe by Eagle cement road (now Dangote). This was premeditated by the industrial activities and high employment rate within the study area. Three sample points for each station made up of three composite samples were made labelled $R, S, T$ selected based on distance from target cement factory $(100 \mathrm{~m}, 250 \mathrm{~m}$ and $400 \mathrm{~m}$ respectively) and corresponding control points of Rc, Sc and Tc respectively were used. The Nutri-chemical parameters of pH, DO, NO3-, PO43-, SO42-, NH4+ were determined using Horiba pH meter, Modified Azide or Winkler Method, Ultraviolet Spectrophotometric Screening Method, Stannous Chloride Method, Turbidimetric method and the Phenate method respectively (all parameters measured in $\mathrm{mg} / \mathrm{l}$ except $\mathrm{pH}$ in units). Result showed the following ranges for pH, DO, NO3-, PO43-, SO42-, NH4+ were 7.14 $\pm 0.01-7.22 \pm 0.01,0.00 \pm 0.00-0.58 \pm 0.26,4.45 \pm 0.06$ $4.75 \pm 0.08,5.10 \pm 0.23-6.30 \pm 0.30,0.40 \pm 0.12-0.90 \pm 0.20$ and $2.68 \pm 0.36-3.70 \pm 0.22$ respectively. The results showed that $p H$, nitrates and sulphates were within regulatory limits (WHO, NSDWQ, FEPA, NESREA, USEPA, SON etc) but DO, phosphate and ammonia are much above allowable limits by these regulatory agencies which poses great danger to both ground water and water usage for other beneficial uses. The oneway ANOVA and t-test showed no significant variations ( $p<0.05)$. There must be deliberate attempt by relevant agencies to monitor the indiscriminate waste dump, effluents and anthropogenic inputs within this area as residential safety, hence groundwater pollution is gradual been threatened.
\end{abstract}

Keywords: Dangote, DO, drains, effluent, Nutri-chemical, pH, phosphate,

\section{INTRODUCTION}

According to Muhammed et al. (2016), most developing countries like Nigeria have challenges relating to clean water supply and adequate sanitation services, hence are prone to diseases associated with water and poor sanitation. According to Muhammed et al. (2016), such diseases are diarrhea, impetigo and trachoma. Very high percentages of such cases linked to diarrhoea are due to unsafe water, poor sanitary habits and hygiene globally (WHO/UNICEF, 2009). Poor water quality is considered as one of the practical proofs of poverty in developing countries. Accordingly, UN (2015) observed that improvement in drinking water supply, quality, sanitation and reducing waterborne diseases have been major components of the sustainable development goal (SDG) programmes in goal 6 formulated.

The effort to deliver safe water to the population has faced many encumbrances such as population growth, poor sanitation, and contamination of water sources with domestic wastes and industrial effluents (Alemu et al., 2015; Troyer et al., 2016). This showed that despite worldwide efforts of delivering safe drinking water, the transmission of waterborne diseases is still a matter of major concern. Industrial development is often associated with the generation of industrial effluents which can bring about water, sediment and soil pollution if not monitored and controlled (Fakayode, 2005).

The $\mathrm{pH}$ of water is the degree of acidity or alkalinity and or the negative logarithm of the water. The term " $\mathrm{pH}$ " refers to the measurement of hydrogen ion activity in the solution (vlab.amrita.edu. 2012). The $\mathrm{pH}$ is measured on a scale of 0 to 14 , with lower values indicating high $\left[\mathrm{H}^{+}\right]$(more acidic) and 
higher values indicating low $\left[\mathrm{H}^{+}\right]$ion activity (less acidic). A pH of 7 is considered as neutral. Every whole unit in $\mathrm{pH}$ represents a ten-fold increase or decrease in hydrogen ion concentration. According to Duressa et al. (2019), most natural waters possess $\mathrm{pH}$ values ranging from 5.0 to 8.5. Rain water has a $\mathrm{pH}$ value of 5.4 to 6.0 , which then reacts with soils and minerals causing the reduction in $\left[\mathrm{H}^{+}\right]$and thus the water may become alkaline with a $\mathrm{pH}$ of 8.0-8.5 (vlab.amrita.edu., 2012). Raw wastewater generally has a pH near neutral (7.0), although it may vary between 6 and 8 based on previous studies. Low $\mathrm{pH}$ in water is usually caused by either low influent $\mathrm{pH}$ or low alkalinity water with nitrification (Duressa, et al., 2019).

Chemical parameters such as $\mathrm{pH}$, nitrate, and others are widely accepted as other critical water quality parameters for drinking water (Duressa et al., 2019). These parameters either directly influence microbiological quality or affect disinfection efficiencies and human health (Duressa et al., 2019). According to Joshi et al. (2009), the six main indicators of water quality includes dissolved oxygen (DO), nitrate $\left(\mathrm{NO}_{3}{ }^{-}\right)$, phosphate $\left(\mathrm{PO}_{4}{ }^{3-}\right)$ etc. The high demand for potable water vis a vis its scarcity makes it a necessity for conservation and even treatment for various beneficial uses. Other nutrient parameters of interest are ammonium $\left(\mathrm{NH}_{4}^{+}\right)$and sulphates $\left(\mathrm{SO}_{4}{ }^{2-}\right)$ (Iyama et al., 2016).

This preliminary study offers good literature to the academia, government and the notary public especially those living within that vicinity of the pending and increasing concentration of nutrient and bacteriological parameters due to the influence of industrial actions, waste dump and human activities around them on their ground and surface water quality. Therefore, the need to investigate the concentrations of selected nutri-chemical parameters such as nitrates, sulphates, phosphates, ammonium $\mathrm{pH}$ and $\mathrm{DO}$ at the drains where effluent of these industries discharge their effluents was carried out.

\section{Materials ANd Methods}

\subsection{Site Selection and Location}

Samples of wastewater from the drains were collected from 3 different sites along the stretch of the drainage adjoining the study stations in 3 composite sites for each station. These study stations are labelled R, S and T which were $100 \mathrm{~m}, 250 \mathrm{~m}$ and $400 \mathrm{~m}$ respectively away from the cement and gas stations at the Iwofe- Rumuolumeni axis of Port Harcourt. Site selection was guided by the presence of certain influential anthropogenic activities. These activities range from the industrial, waste dumps and drinking bars. The geographical location was mapped using a Techno android phone installed GPS. The following locations for the composited site samples were R $\left(4^{\circ} 47^{\prime} 53^{\prime \prime} \mathrm{N}\right.$ and $6^{\circ} 56^{\prime} 36^{\prime \prime} \mathrm{E}, \mathrm{S}\left(4^{\circ} 48^{\prime} 23^{\prime \prime} \mathrm{N}\right.$ and $\left.6^{\circ} 56^{\prime} 16^{\prime \prime} \mathrm{E}\right)$, and $\mathrm{T}\left(4^{\circ} 48^{\prime} 42^{\prime \prime} \mathrm{N}\right.$ and $\left.6^{\circ} 56^{\prime} 35^{\prime \prime} \mathrm{E}\right)$ with the following corresponding control stations

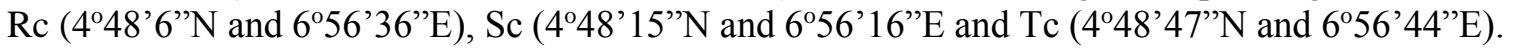

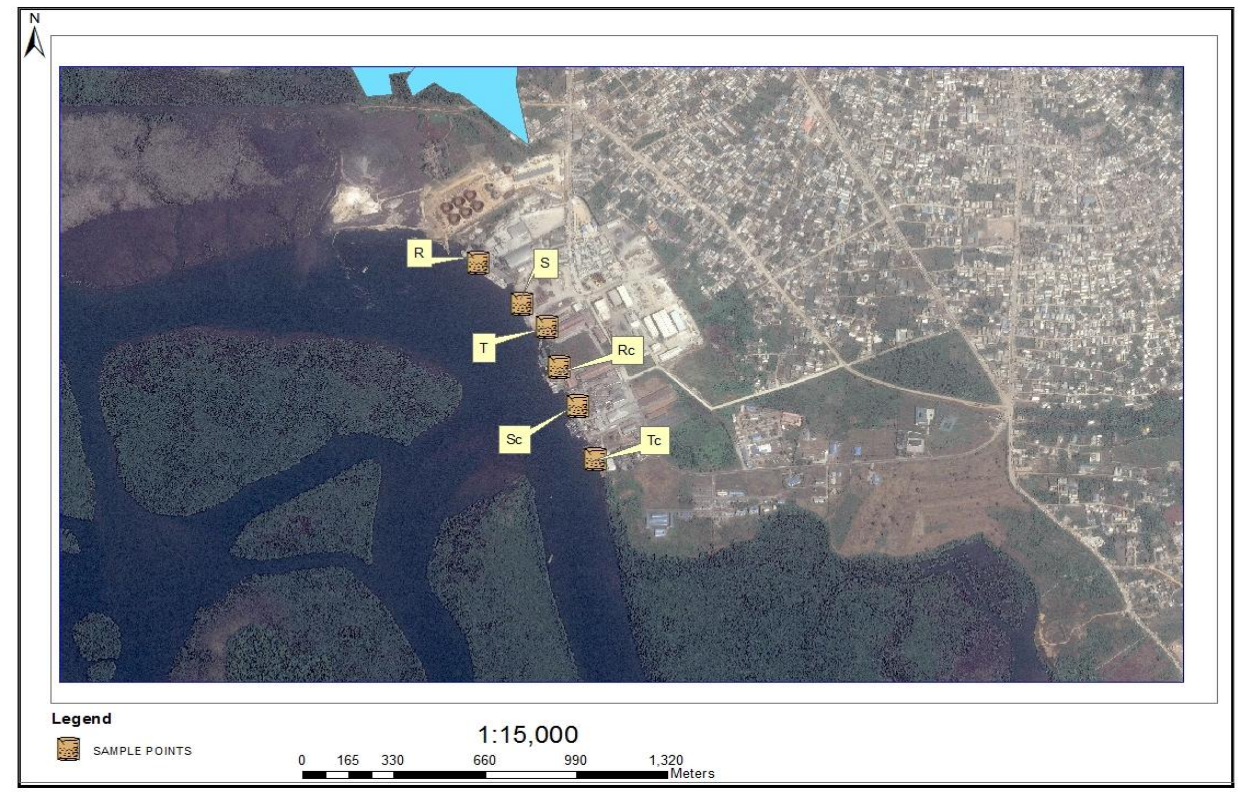

Figure1. Study Locations Showing Dangote Cement Drain Water 


\subsection{Sample Collection}

The effluent water samples were collected using water sampler to a depth of about $20 \mathrm{~cm}$ below the water surface to avoid surface borne particles (which in most cases are temporal) being part of the samples. Three (3) samples were taken from each station and then composited to make up the three stations of R, S, T respectively. These stations are monitored by the control samples around each station labelled Rc, Sc and Tc respectively. The Nutri-chemical samples were placed in a 2-litre plastic container previously rinsed with the sample purported to be collected and sealed correctly.

The water samples collected were then stored in ice-packed coolers and preserved in accordance with part VII Section D of the DPR Environmental Guidelines and Standards. Laboratory analysis of the nutri-chemical parameters were done in compliance to standard practice by DPR Environmental Guidelines and Standards (DPR/EGASPIN, 2002). Laboratory methodologies for wastewater were adopted from Standard Methods for the Examination of Water and Wastewater, $19^{\text {th }}$ Edition, 1995.

\subsubsection{Dissolved Oxygen (DO) Determination}

DO was analyzed using the Winkler Methods (APHA, 1998). Fill a $70 \mathrm{ml}$ BOD bottle with $0.5 \mathrm{ml}$ of manganous sulphate solution (Winkler I) and $0.5 \mathrm{ml}$ alkali-iodide-azide reagent (Winkler II). This was stoppered to exclude air bubbles and mixed by several inversions. This is followed by the addition of $0.5 \mathrm{ml}$ concentrated $\mathrm{H}_{2} \mathrm{SO}_{4}$ after about 5-10 minutes, re-stoppered and mixed for complete dissolution of precipitate. Finally, observing all necessary quality control measures and preservation, the fixed samples were moved to the Institute of Pollution Studies (IPS) of the Rivers State University, Port Harcourt, Nigeria laboratory for further analytical processes.

\subsubsection{Nitrate $\left(\mathrm{NO}_{3}{ }^{-}\right)$}

Nitrate was measured by the Ultraviolet (UV) Spectrophotometric Screening Method. A $1.0 \mathrm{ml} \mathrm{HCl}$ solution was added to $50 \mathrm{ml}$ clear sample and properly mixed. The nitrate concentration was obtained from the standard curve from absorbance measurements at a wavelength of $220 \mathrm{~nm}$. The limit of detection was $0.05 \mathrm{mg} / \mathrm{l}$.

\subsubsection{Phosphate $\left(\mathrm{PO}_{4}{ }^{3-}\right)$ Determination}

This is determined by the Stannous Chloride Method (APHA, 1992). To 50ml sample, 2.0ml ammonium molybdate reagent and $0.2 \mathrm{ml}$ stannous chloride reagent and mixed properly. After adding the stannous chloride (after about 10-12 minutes), the absorption of the treated sample is read off on spectronic $21 \mathrm{D}$ at $690 \mathrm{~nm}$. Finally, phosphate level is obtained by reading off the absorption level from standard curve using $0.05 \mathrm{mg} / \mathrm{l}$ detection limit.

\subsubsection{Sulphate Determination}

Sulphate was determined using the turbidimetric method (APHA, 1995). To a 50ml sample or portion diluted to $50 \mathrm{ml}$ contained in a conical flask, $2.5 \mathrm{ml}$ of conditioning reagent (a mixture of $50 \mathrm{ml}$ glycerol with a solution of $30 \mathrm{ml}$ concentrated $\mathrm{HCl}, 300 \mathrm{ml}$ distilled water, $100 \mathrm{ml} 95 \%$ ethanol and $75 \mathrm{~g}$ sodium chloride) and a quarter spatula full barium chloride $\left(\mathrm{BaCl}_{2}\right)$. The mixture was swirled for a minute and the barium sulphate $\left(\mathrm{BaSO}_{4}\right)$ turbidity read off at the $5^{\text {th }}$ minute on the Spectronic $21 \mathrm{D}$ at $420 \mathrm{~nm}$ against water. Sulphate level was read from a calibration curve prepared for sulphate standards treated the same way as the samples using $1.0 \mathrm{mg} / \mathrm{l}$ detection limit.

\subsubsection{Ammonia Determination}

Ammonia can be determined by the Phenate method. To a $25 \mathrm{ml}$ sample in $50 \mathrm{ml}$ Erlenmayer flask, the following were added; $1 \mathrm{ml}$ sodium nitroprusside solution, 2.5 oxidizing solution and $1 \mathrm{ml}$ phenol solution. The samples were covered for 1 hour to allow for the colour development at an absorbance of $630 \mathrm{~nm}$ and the concentration calculated by reference to the standard curve at a detection limit of $<0.02 \mathrm{mg} / \mathrm{l}$.

\subsection{Summary of Analytical Technique}

The following analytical techniques and guidelines were employed for the analysis of the parameters under study. All quality control measures were made and standard methods for examination of water and wastewater was also adopted. Table 1 shows the summary of analytical techniques employed for Nutri-chemical. 
Assessment of Nutri-Chemical Concentration Levels of Wastewater from Drains Adjacent Cement and Associated Factories in Port Harcourt, Nigeria

Table1. Summary of Analytical Techniques for the Nutri-chemical Parameters

\begin{tabular}{|l|l|c|}
\hline Parameters & Analytical Methods/Techniques & Wavelengths of Operation \\
\hline $\mathrm{pH}$ & Horiba water Checker (model U-10) & - \\
\hline $\mathrm{DO}(\mathrm{Mg} / \mathrm{L})$ & Winkler Method (APHA, 1998) & - \\
\hline $\mathrm{NO}_{3}{ }^{-}(\mathrm{mg} / \mathrm{L})$ & Ultraviolet Spectrophotometric Screening Method & $220 \mathrm{~nm}$ \\
\hline $\mathrm{PO}_{4}{ }^{3-}(\mathrm{mg} / \mathrm{L})$ & Stannous Chloride Method (APHA, 1995) & $690 \mathrm{~nm}$ \\
\hline $\mathrm{SO}_{4}{ }^{2-}(\mathrm{mg} / \mathrm{L})$ & Turbidometric method (APHA, 1995) & $420 \mathrm{~nm}$ \\
\hline $\mathrm{NH}_{4}{ }^{+}(\mathrm{mg} / \mathrm{L})$ & Phenate method & $630 \mathrm{~nm}$ \\
\hline
\end{tabular}

\subsection{Statistical Analysis}

Data obtained from the laboratory analysis of the water samples were analyzed using descriptive and inferential statistical techniques, notably tables, mean and one-way analysis of variance (ANOVA).

\section{RESULTS AND DISCUSSIONS}

The results of the nutri-chemical parameters in April, May and June for the different stations of $\mathrm{R}, \mathrm{S}$ and $\mathrm{T}$ are shown in Tables 2, 3 and 4 while the temporal and spatial mean concentrations for the nutrichemical parameters are in Tables 5 and 6 respectively. The concentrations of ammonium $\left(\mathrm{NH}_{4}^{+}\right)$for the study stations of R, S, T in the months of April, May and June were 3.50 $\pm 0.20,3.45 \pm 0.16,2.70 \pm 0.37$ with control of $0.90 ; 3.40 \pm 0.15,3.50 \pm 0.22,2.68 \pm 0.36$ and control of 1.00 and $3.48 \pm 0.06,3.70 \pm 0.22$, $3.00 \pm 0.28$ and control of 1.20 respectively. The ranges for the Nutri-chemical parameters are shown in Table 7.

The concentrations of $\mathrm{pH}$ (units) in the study stations of $\mathrm{R}, \mathrm{S}$ and $\mathrm{T}$ for the months of April, May and June respectively were $7.18 \pm 0.01,7.15 \pm 0.01,7.14 \pm 0.00$ while the control station was $7.15 ; 7.17 \pm 0.01$, $7.16 \pm 0.01,7.16 \pm 0.00$ and control of 7.15 and $7.22 \pm 0.01,7.22 \pm 0.01,7.20 \pm 0.00$ and control of 7.14. The $\mathrm{pH}$ of the drain water was within the range established by regulatory agencies of 6.5-9 (NSDWQ, 2008; WHO, 2004; NESREA, 2011). This agrees with the range obtained in earlier research (Dimowo, 2013; Tesfamariam \& Younis, 2016; Akoto et al. 2008; FEPA, 1991). The range of $\mathrm{pH}$ (7.14-7.22) shows that the surface water drains was alkaline as aquatic organisms are heavily affected by $\mathrm{pH}$, most of their metabolic activities are $\mathrm{pH}$ dependent (Fakayode, 2005). Various researches have shown the impact of industrial activities on the physico-chemical parameters of rivers and streams (Adekunle \& Eniola, 2008; Ogedengbe \& Akinbile, 2004; Fakayode, 2005; Akoto et al., 2008). This alkaline nature of the drain water may be linked to certain alkaline inducing substances and soil content. The relatively small variation between the $\mathrm{pH}$ values from those of the control station is an indication of little or no impact of anthropogenic manipulations. The mean $\mathrm{pH}$ levels of all the samples were found to be well below and outside the tolerable range as specified by the Environmental Conservation Regulations (ECR) and met the National Drinking Water Quality Standards (NDWQS) for rural surface water supply systems (NDWQS, 2008).The major sources of pollution were observed to be effluents from the industries and dump sites within and around the Creek catchment (Ewa et al., 2011). The highest level of $\mathrm{pH}$ was found down the junction by Iwofe road by June. This may be attributed to the higher rate of serial dilution from precipitation which increases the $\mathrm{pH}$ impacting high alkalinity to the drain water. Stream flow direction is critical to protecting water quality and preserving aquatic habitat (Ugbaja \& Ephraim, 2019). The least value of $\mathrm{pH}$ values were found in the months of April and May which may also emanate from concentration factor due to draught. The spatial increase was also observed in stations $\mathrm{R}$ and $\mathrm{S}$ due to the impacts of minor industrial and human inputs upstream of the road.

The DO (mg/l) for stations R, S, T in April, May and June were $0.05 \pm 0.01,0.04 \pm 0.01,0.01 \pm 0.01$ and control of $0.50 ; 0.50 \pm 0.21 ; 0.05 \pm 0.11,0.58 \pm 0.26$ and control of $1.20 ; 0.01 \pm 0.00,0.01 \pm 0.00 ; 0.00 \pm 0.00$ and control of 8.50 respectively. The DO ( $\mathrm{mg} / \mathrm{l})$ concentration is comparatively very low and shows that the water body lacks dissolved oxygen and below the permissible limits (WHO, 2004; NSDWQ, 2008; GoN, 2012). Dissolved Oxygen is a measure of the amount of oxygen dissolved in the given water or water body (Iyama, Brown \& Okpara, 2018). According to Iyama and Edori (2014), DO is essential in the determination of water quality index of a creek water body such as that of the Imonite, Ndoni in Nigeria. These concentrations were far below those of similar research by Ugbaja and Ephraim (2019) whose values were even above WHO (2004) permissible limits. These relatively low values may reflect early indication of undesirable conditions in the physical, chemical and biochemical factors 
within the water bodies (Ugbaja \& Ephraim (2019). This was relatively lower than those recorded by Ewa et al. (2011) and on the impact of industrial activities on water quality of Omoku Creek, Nigeria. The values were also lower than those earlier observed by Dimowo (2013) on the assessment of some physico-chemical parameters of River Ogun Abeokuta, Ogun State, Nigeria. The water from these sources may also be contaminated with domestic and municipal, agricultural, surface run-off, industrial wastes and accidental spillage and which is likely to cause water related diseases (Ojekunle, 2000; Walsh, 1980). Definitively, Ewa et al. (2011) posited that dissolved oxygen (DO) is a measure of the degree of pollution by organic matter, the destruction of organic substances as well as the selfpurification capacity of the water body. According to Iyama et al. (2018), the concentration of DO is a function of the biological activities prevalent in the body of water, but the main sources of DO in water are diffusion of oxygen from surrounding air, photosynthetic activities and aeration of water resulting from tumbled over falls and rapids. High or low $\mathrm{pH}$ values in in rivers affect aquatic life and alter the toxicity of other pollutant in one form or the other (Morrison et al., 2001). Similarly, DO in liquid provide a source of oxygen needed for the oxidation of organic matter when the concentration whose deficiency causes the water body to become dead or devoid of aquatic life (Chukwu, 2008).

Nitrate $\left(\mathrm{NO}_{3}{ }^{-}\right.$in $\left.\mathrm{mg} / \mathrm{l}\right)$ concentrations for the study stations $\mathrm{R}, \mathrm{S}, \mathrm{T}$ in April, May and June were $4.50 \pm 0.09,4.65 \pm 0.01,4.75 \pm 0.08$ and control of $2.35 ; 4.45 \pm 0.06 ; 4.50 \pm 0.02,4.65 \pm 0.08$ and control of 2.30; and $4.50 \pm 0.01,4.52 \pm 0.00,4.55 \pm 0.02$ with control of 2.50 respectively. The amount of nitrate $\left(\mathrm{NO}_{3}{ }^{-}\right)$in the study ranged between 4.45 to $4.75 \mathrm{mg} / \mathrm{l}$ but was found highest at April but least in June. This was similar to the range of 2.2-6.5mg/l recorded earlier (Duressa et al., 2019). The observed values of nitrate in the present work were above the range earlier recorded by Raj and Sevarkodiyone (2018) in a studied pond whose range was $0-0.40 \mathrm{mg} / \mathrm{l}$ but fall within the range of $2.1-12.8 \mathrm{mg} / \mathrm{l}$ values reported by Simpi et al. (2011) in Hosahalli Tank, Karnataka. This also be linked to the impact of dilution effect of rains higher in June but lower by March and followed by May. According to Iyama et al. (2018), nitrate is the most stable form of nitrogen and also the commonest form in natural and fresh domestic wastewater and could also be found in the effluent of nitrifying biological treatment plants (occurs up to $30 \mathrm{mg}$ ) nitrate as nitrogen per litre. In most cases, the contamination resulting from the presence of nitrate and phosphate leads to eutrophication hence reduction in water quality (Iyama et al. (2018). The values so obtained were all below the permissible limits by WHO $(45 \mathrm{mg} / \mathrm{l})$ and NSDWQ $(10 \mathrm{mg} / \mathrm{l})$ for surface water (WHO, 2004; NSDWQ, 2008). Nitrates are forms of nitrogen found in several different forms in terrestrial and aquatic ecosystems. The main forms of nitrogen are ammonia $\left(\mathrm{NH}_{3}\right)$, nitrates $\left(\mathrm{NO}_{3}{ }^{-}\right)$, and nitrites $\left(\mathrm{NO}_{2}\right)$ (USEPA, 1986). These concentrations were higher than those recorded by Dimowo (2013) in assessment of some physico-chemical parameters of River Ogun, Abeokuta, Ogun State, Nigeria. The variation in nitrate content of the wastewater was within similar range for earlier studies (Ugbaja \& Ephraim (2019). According to Ugbaja \& Ephraim (2019), most of the dry season samples had elevated nitrate levels that exceeded the $10 \mathrm{mg} / \mathrm{l}$ permissible limits of the Nigerian standard for drinking water quality which is similar to the observed trend though not as high as this (NSDWQ, 2008), hence the water is polluted by nitrate. Nitrate is essential for growth hence high concentration of nitrate indicates eutrophication which impairs water quality (Ugbaja \& Ephraim, 2019). Though, nitrate itself is not a direct toxicant to human but constitutes a health hazard through conversion to nitrite, which reacts with blood haemoglobin to cause methemoglobinemia in infants less than 6 months old (Ugbaja \& Ephraim, 2019). The source of nitrate in most surface water is associated with geological, agricultural and anthropogenic performers. However, in the absence of nitrogen-bearing rocks, the enrichment of nitrate in the study area can be attributed to fertilizer usage, seasonal influence of biomass burning, harmattan dust during the dry season and leachates from human and animal sewages, pit latrines and refuse dump located close to streams (Ugbaja \& Ephraim, 2019).

Similarly, sulphate $\left(\mathrm{SO}_{4}{ }^{2-}\right)$ concentrations in the study stations of $\mathrm{R}, \mathrm{S}, \mathrm{T}$ for the months of April, May and June were $0.45 \pm 0.12,0.50 \pm 0.08,0.90 \pm 0.20$ and control of $0.45 ; 0.40 \pm 0.12,0.50 \pm 0.05,0.80 \pm 0.16$ and control of 0.40 ; and $0.55 \pm 0.04,0.60 \pm 0.00,0.65 \pm 0.04$ and control of 0.50 respectively. The concentration of sulphate $\left(\mathrm{SO}_{4}{ }^{2-}\right.$ in $\left.\mathrm{mg} / \mathrm{l}\right)$ in the study stations showed a range of $0.45-0.90$ (April), 0.400.80 (May) and 0.55-0.65 (June) but the overall range was 0.40-0.90 mg/l. These concentrations were really below the permissible limits as recommended by NAFDAC, SON, FEPA, NSDW, WHO, EU and USEPA (NSDWQ, 2008; WHO, 2004). These values were relatively higher than those earlier observed as this amount may likely emanate from waters coming from agricultural fertilizer runoff entering surface waters by rain drainage (Ugbaja \& Ephraim, 2019). Natural water frequently contains 
impurities that come from natural or anthropogenic sources (Adeyeye, 1994; Asaolu et al., 1997). High sulphate levels in waters may be due to agricultural and anthropogenic activities (Ephraim \& Ajayi, 2015). Other factors to elevated levels of Sulphate in surface water are types of minerals occurring in the watershed, acid rain and others (Ugbaja \& Ephraim, 2019). Sulphate levels may also be attributed to the use of barium sulphate as additive in various plastic products dumped around the abandoned waste site (Ellila, 2011). According to Iyama et al. (2018), the reduction of sulphates to sulphides (particularly $\mathrm{H}_{2} \mathrm{~S}$ ) causes odour and corrosion problems and also scaling in industrial water supplies and can have laxative effect on man. Sulphates may also be produced through leachates from human and animal sewages, pit latrines and refuse dump located close to streams or water bodies (Ugbaja \& Ephraim, 2019).

Phosphate $\left(\mathrm{PO}_{4}{ }^{3-}\right)$ concentration for the months of April, May, June and the study stations of $\mathrm{R}, \mathrm{S}, \mathrm{T}$ were $6.20 \pm 0.49,5.15 \pm 0.25,5.16 \pm 0.24$ with control of $5.50 ; 6.00 \pm 0.41,5.10 \pm 0.23,5.15 \pm 0.19$ and control of 1.00; and $6.30 \pm 0.30,5.50 \pm 0.26,5.80 \pm 0.05$ with control of 1.20 respectively. The concentration of phosphate $\left(\mathrm{PO}_{4}{ }^{3-}\right.$ in $\left.\mathrm{mg} / \mathrm{l}\right)$ in the study stations showed a range of 5.15-6.20 (April), 5.10-6.00 (May) and 5.50-6.30 (June) while the overall range was 5.10-6.30 mg/l. These values are found to be slightly above the WHO limit of $5 \mathrm{mg} / \mathrm{l}$ and 3.5 limit for NESREA (National Environmental Standards and Regulations Enforcement Agency, Nigeria) and extremely below the NSDWQ limit of $100 \mathrm{mg} / \mathrm{l}$ though the relatively high concentration of phosphate above WHO (2004) limit can be attributed to the increased use of phosphates in the form of fertilizers for enhanced plant growth and its use in meat processing and poultry production industries (Chien, Prochnow \& Cantarella, 2009; Bach Son Long, Gál \& Buňka, 2011). This concentration of phosphate is higher than those observed by Duressa, et al., (2019) in another water body earlier (range, $0.65-1.0 \mathrm{mg} / \mathrm{l}$ ). Total phosphate-phosphorus value exceeding $0.1 \mathrm{mg} / \mathrm{l}$ can lead to accelerated growth, eutrophication, problems and natural water degradation (Water Resource Centre WRC, 2014). This could lead to problems if the effluents were to be released into the water bodies (Ugbaja \& Ephraim, 2019). High concentrations of phosphate are often responsible for eutrophic conditions in water bodies (Ugbaja \& Ephraim, 2019). Phosphates enter waterways from human and animal waste, phosphorus rich bedrock, laundry, cleaning, industrial effluents, and fertilizer runoff and become detrimental when they over fertilize aquatic plants and cause stepped up eutrophication (WRC, 2014). Too much phosphate can lead to death of aquatic organisms especially the presence of orthophosphate (WRC, 2014). Phosphates are not toxic to people or animals unless they are present in very high levels though digestive problems could occur from extremely high levels of phosphate (WRC, 2014). Conversely, these values were also higher than those obtained by Raj $\&$ Sevarkodiyone (2018) in a studied pond (0.36 to $2.86 \mathrm{mg} / \mathrm{L})$.

The concentrations of ammonium $\left(\mathrm{NH}_{4}{ }^{+}, \mathrm{mg} / \mathrm{l}\right)$ for the study stations of $\mathrm{R}, \mathrm{S}, \mathrm{T}$ in the months of April, May and June were $3.50 \pm 0.20,3.45 \pm 0.16,2.70 \pm 0.37$ with control of $0.90 ; 3.40 \pm 0.15,3.50 \pm 0.22$, $2.68 \pm 0.36$ and control of 1.00 ; and $3.48 \pm 0.06,3.70 \pm 0.22,3.00 \pm 0.28$ and control of 1.20 respectively. The range of $\mathrm{NH}_{4}{ }^{+}$in the study station was $2.68-3.70 \mathrm{mg} / \mathrm{l}$. These values were higher than both NSDWQ and WHO permissible limits of $1.0 \mathrm{mg} / \mathrm{l}$ and $0.5 \mathrm{mg} / \mathrm{l}$ respectively. The values observed in the water from the drains were relatively higher than those earlier reported by Ugbaja and Ephraim (2019) on the physicochemical and bacteriological parameters of surface water quality in part of Oban Massif, Nigeria. According to earlier works by Ogedengbe and Akinbile (2004), industrial waste remains the most common source of water pollution in the presentday Nigeria. Ammonia and nitrite are more toxic than nitrate in the aquatic environment (Dimowo, 2013). Wastewater contains pollutants in the form of carbon (cBOD) and ammonia nitrogen $\left(\mathrm{NH}_{3}\right)$, hence anything which limits the effectiveness of the nitrifying bacteria to convert ammonia to nitrate will cause the aeration tank effluent ammonia concentrations to increase, an indication of loss of control. Nitrification is a two-step process for the removal of ammonia from wastewater using two different types of autotrophic bacteria which oxidizes ammonia to nitrite (nitrosomonas) and then oxidize nitrite to nitrate (nitrobacter). Ammonia is toxic to both fish and invertebrates and ammonia in water is an indication of low chlorine levels. The USEPA recommends a limit of $0.02 \mathrm{mg} / \mathrm{l}$ for $\mathrm{NH}_{3}$ in freshwater or marine environments. Research has shown that total ammonia levels, at this limit, can range from $160 \mathrm{mg} / \mathrm{l}$ at $\mathrm{pH} 6$ and temperature of $5^{\circ} \mathrm{C}$ degrees $\mathrm{C}$ to $0.06 \mathrm{mg} / \mathrm{l}$ at $\mathrm{pH} 9$ and temperature of $25^{\circ} \mathrm{C}$. Domestic sewage typically contains 20 to 40 $\mathrm{mg} / \mathrm{l}(\mathrm{ppm})$ of ammonia nitrogen $\left(\mathrm{NH}_{4}-\mathrm{N}\right)$, hence at small concentrations; ammonia can cause significant deterioration to the flora and fauna in the body of water receiving it. Analysis of physicochemical parameters of the various wastewater categories yielded range of $0.00-0.72 \mathrm{mg} / \mathrm{l}$ of NH $\mathrm{N}_{3}-\mathrm{N}$ in 
Assessment of Nutri-Chemical Concentration Levels of Wastewater from Drains Adjacent Cement and Associated Factories in Port Harcourt, Nigeria

wastewater of a fertilizer-factory-waste discharge equalization basin which was far lower than the results of this study (Uba, 1995). According to Habermayer and Sanchez (2005), nitrification process can occur at DO levels as low as $1 \mathrm{mg} / \mathrm{l}$ as aeration can reduce ammonia levels through physical means. Ammonia levels in wastewater can be reduced through the process of desorption (Patoczka \& Wilson, 1984). Industries turn out wastes which are peculiar in terms of type, volume and frequency (Adekunle, 2008). The colour and odour of the wastewater samples were turbid and objectionable in consonance with those earlier observed for Urinjikulam pond water (Raj \& Sevarkodiyone, 2018). Pollution of water is measured by assessing the physiochemical parameters of water (Wankhade, Manwar, \& Malu, 2012).

Table2. Nutri-chemistry of Drain Wastewater (April, 2020)

\begin{tabular}{|l|l|l|l|l|}
\hline \multirow{2}{*}{ Parameters } & \multicolumn{4}{|c|}{ Stations } \\
\cline { 2 - 5 } & $\mathrm{R}$ & $\mathrm{S}$ & $\mathrm{T}$ & Control \\
\hline $\mathrm{pH}$ & $7.18 \pm 0.01$ & $7.15 \pm 0.01$ & $7.14 \pm 0.00$ & 7.15 \\
\hline $\mathrm{DO}(\mathrm{mg} / \mathrm{L})$ & $0.05 \pm 0.01$ & $0.04 \pm 0.01$ & $0.01 \pm 0.01$ & 0.50 \\
\hline $\mathrm{NO}_{3}{ }^{-}(\mathrm{mg} / \mathrm{L})$ & $4.50 \pm 0.09$ & $4.65 \pm 0.01$ & $4.75 \pm 0.08$ & 2.35 \\
\hline $\mathrm{PO}_{4}{ }^{-2}(\mathrm{mg} / \mathrm{L})$ & $6.20 \pm 0.49$ & $5.15 \pm 0.25$ & $5.16 \pm 0.24$ & 5.50 \\
\hline $\mathrm{SO}_{4}{ }^{2-}(\mathrm{mg} / \mathrm{L})$ & $0.45 \pm 0.12$ & $0.50 \pm 0.08$ & $0.90 \pm 0.20$ & 0.45 \\
\hline $\mathrm{NH}_{4}{ }^{+}(\mathrm{mg} / \mathrm{L})$ & $3.50 \pm 0.20$ & $3.45 \pm 0.16$ & $2.70 \pm 0.37$ & 0.90 \\
\hline
\end{tabular}

Table3. Nutri-chemistry of Drain Wastewater (May, 2020)

\begin{tabular}{|l|l|l|l|l|}
\hline \multirow{2}{*}{ Parameters } & \multicolumn{4}{|c|}{ Stations } \\
\cline { 2 - 5 } & $\mathrm{R}$ & $\mathrm{S}$ & $\mathrm{T}$ & Control \\
\hline $\mathrm{pH}$ & $7.17 \pm 0.01$ & $7.16 \pm 0.01$ & $7.16 \pm 0.00$ & 7.15 \\
\hline $\mathrm{DO}(\mathrm{mg} / \mathrm{L})$ & $0.50 \pm 0.21$ & $0.05 \pm 0.11$ & $0.58 \pm 0.26$ & 1.20 \\
\hline $\mathrm{NO}_{3}{ }^{-}(\mathrm{mg} / \mathrm{L})$ & $4.45 \pm 0.06$ & $4.50 \pm 0.02$ & $4.65 \pm 0.08$ & 2.30 \\
\hline $\mathrm{PO}_{4}{ }^{-2}(\mathrm{mg} / \mathrm{L})$ & $6.00 \pm 0.41$ & $5.10 \pm 0.23$ & $5.15 \pm 0.19$ & 1.00 \\
\hline $\mathrm{SO}_{4}{ }^{-2}(\mathrm{mg} / \mathrm{L})$ & $0.40 \pm 0.12$ & $0.50 \pm 0.05$ & $0.80 \pm 0.16$ & 0.40 \\
\hline $\mathrm{NH}_{4}{ }^{-}(\mathrm{mg} / \mathrm{L})$ & $3.40 \pm 0.15$ & $3.50 \pm 0.22$ & $2.68 \pm 0.36$ & 1.00 \\
\hline
\end{tabular}

Table4. Nutri-chemistry of Drain Wastewater (June, 2020)

\begin{tabular}{|l|c|l|l|l|}
\hline \multirow{2}{*}{ Parameters } & \multicolumn{4}{|c|}{ Stations } \\
\cline { 2 - 5 } & $\mathrm{R}$ & $\mathrm{S}$ & $\mathrm{T}$ & Control \\
\hline $\mathrm{pH}$ & $7.22 \pm 0.01$ & $7.22 \pm 0.01$ & $7.20 \pm 0.00$ & 7.14 \\
\hline $\mathrm{DO}(\mathrm{mg} / \mathrm{L})$ & $0.01 \pm 0.00$ & $0.01 \pm 0.00$ & $0.00 \pm 0.00$ & 8.50 \\
\hline $\mathrm{NO}_{3}{ }^{-}(\mathrm{mg} / \mathrm{L})$ & $4.50 \pm 0.01$ & $4.52 \pm 0.00$ & $4.55 \pm 0.02$ & 2.50 \\
\hline $\mathrm{PO}_{4}{ }^{3-}(\mathrm{mg} / \mathrm{L})$ & $6.30 \pm 0.30$ & $5.50 \pm 0.26$ & $5.80 \pm 0.05$ & 1.20 \\
\hline $\mathrm{SO}_{4}{ }^{-}(\mathrm{mg} / \mathrm{L})$ & $0.55 \pm 0.04$ & $0.60 \pm 0.00$ & $0.65 \pm 0.04$ & 0.50 \\
\hline $\mathrm{NH}_{4}{ }^{+}(\mathrm{mg} / \mathrm{L})$ & $3.48 \pm 0.06$ & $3.70 \pm 0.22$ & $3.00 \pm 0.28$ & 1.20 \\
\hline
\end{tabular}

Table5. Temporal mean concentration for Nutri-chemical parameters in drain Wastewater

\begin{tabular}{|l|l|l|l|l|}
\hline \multirow{2}{*}{ Parameters } & \multicolumn{4}{|c|}{ Stations } \\
\cline { 2 - 5 } & $\mathrm{R}$ & $\mathrm{S}$ & $\mathrm{T}$ & Control \\
\hline $\mathrm{pH}$ & $7.16 \pm 0.01$ & $7.16 \pm 0.01$ & $7.21 \pm 0.02$ & 7.15 \\
\hline $\mathrm{DO}(\mathrm{mg} / \mathrm{L})$ & $0.03 \pm 0.04$ & $0.21 \pm 0.09$ & $0.01 \pm 0.05$ & 0.50 \\
\hline $\mathrm{NO}_{3}{ }^{-}(\mathrm{mg} / \mathrm{L})$ & $4.63 \pm 0.05$ & $4.53 \pm 0.02$ & $4.52 \pm 0.03$ & 2.35 \\
\hline $\mathrm{PO}_{4}{ }^{3-}(\mathrm{mg} / \mathrm{L})$ & $5.50 \pm 0.07$ & $5.42 \pm 0.13$ & $5.87 \pm 0.19$ & 1.05 \\
\hline $\mathrm{SO}_{4}{ }^{2-}(\mathrm{mg} / \mathrm{L})$ & $0.62 \pm 0.01$ & $0.57 \pm 0.02$ & $0.60 \pm 0.00$ & 0.45 \\
\hline $\mathrm{NH}_{4}{ }^{+}(\mathrm{mg} / \mathrm{L})$ & $3.22 \pm 0.04$ & $3.19 \pm 0.06$ & $3.39 \pm 0.08$ & 0.90 \\
\hline
\end{tabular}

Table6. Spatial mean concentration for Nutri-chemical parameters in drain Wastewater

\begin{tabular}{|l|l|l|l|l|}
\hline \multirow{2}{*}{ Parameters } & \multicolumn{4}{|c|}{ Stations } \\
\cline { 2 - 5 } & $\mathrm{R}$ & $\mathrm{S}$ & $\mathrm{T}$ & Control \\
\hline $\mathrm{pH}$ & $7.19 \pm 0.01$ & $7.18 \pm 0.00$ & $7.17 \pm 0.01$ & 7.15 \\
\hline $\mathrm{DO}(\mathrm{mg} / \mathrm{L})$ & $0.19 \pm 0.04$ & $0.03 \pm 0.08$ & $0.20 \pm 0.04$ & 3.40 \\
\hline $\mathrm{NO}_{3}{ }^{-}(\mathrm{mg} / \mathrm{L})$ & $4.48 \pm 0.06$ & $4.56 \pm 0.00$ & $4.65 \pm 0.06$ & 2.38 \\
\hline $\mathrm{PO}_{4}{ }^{3-}(\mathrm{mg} / \mathrm{L})$ & $6.17 \pm 0.40$ & $5.25 \pm 0.25$ & $5.37 \pm 0.16$ & 1.08 \\
\hline $\mathrm{SO}_{4}{ }^{2-}(\mathrm{mg} / \mathrm{L})$ & $0.47 \pm 0.08$ & $0.53 \pm 0.04$ & $0.78 \pm 0.13$ & 0.45 \\
\hline $\mathrm{NH}_{4}{ }^{+}(\mathrm{mg} / \mathrm{L})$ & $3.46 \pm 0.16$ & $3.45 \pm 0.15$ & $2.79 \pm 0.31$ & 1.03 \\
\hline
\end{tabular}


Assessment of Nutri-Chemical Concentration Levels of Wastewater from Drains Adjacent Cement and Associated Factories in Port Harcourt, Nigeria

Table7. Ranges for the Nutri-chemical Parameters for Wastewater Drains

\begin{tabular}{|l|l|l|l|l|}
\hline \multirow{2}{*}{ Parameters } & \multicolumn{4}{|c|}{ Stations } \\
\cline { 2 - 5 } & \multicolumn{1}{|c|}{ April } & May & June & Control \\
\hline $\mathrm{pH}$ & $7.16-7.18$ & $7.16-7.17$ & $7.20-7.22$ & $7.14-7.15$ \\
\hline $\mathrm{DO}(\mathrm{mg} / \mathrm{L})$ & $0.01-0.05$ & $0.05-0.58$ & $0.00-0.58$ & $0.05-8.50$ \\
\hline $\mathrm{NO}_{3}{ }^{-}(\mathrm{mg} / \mathrm{L})$ & $4.50-4.75$ & $4.45-4.65$ & $4.50-4.55$ & $2.30-2.50$ \\
\hline $\mathrm{PO}_{4}{ }^{3-}(\mathrm{mg} / \mathrm{L})$ & $5.15-6.20$ & $5.10-6.00$ & $5.50-6.30$ & $1.00-1.20$ \\
\hline $\mathrm{SO}_{4}{ }^{2-}(\mathrm{mg} / \mathrm{L})$ & $0.45-0.90$ & $0.40-0.80$ & $0.55-0.65$ & $0.40-0.50$ \\
\hline $\mathrm{NH}_{4}{ }^{+}(\mathrm{mg} / \mathrm{L})$ & $2.70-3.50$ & $2.68-3.50$ & $3.0-3.70$ & $3.19-3.39$ \\
\hline
\end{tabular}

Table8. Value/Concentration ranges of Nutri-chemical Parameters in Drains and Standard Limits

\begin{tabular}{|l|c|c|c|c|}
\hline Parameters & Present Work & NSDWQ & WHO & USEPA \\
\hline $\mathrm{pH}$ & $7.14-7.22$ & $6.5-9.0$ & $6.5-8.5$ & $6.5-8.5$ \\
\hline $\mathrm{DO}(\mathrm{mg} / \mathrm{L})$ & $0.00-8.50$ & 10 & $5-10$ & $5.5-6.5$ \\
\hline $\mathrm{NO}_{3}{ }^{-}(\mathrm{mg} / \mathrm{L})$ & $2.30-4.75$ & 50 & 45 & 10 \\
\hline $\mathrm{PO}_{4}{ }^{3-}(\mathrm{mg} / \mathrm{L})$ & $1.00-6.30$ & 0.5 & 0.5 & $0.05-0.1$ \\
\hline $\mathrm{SO}_{4}{ }^{2-}(\mathrm{mg} / \mathrm{L})$ & $0.40-0.09$ & 100 & $250-500$ & 250 \\
\hline $\mathrm{NH}_{4}{ }^{+}(\mathrm{mg} / \mathrm{L})$ & $2.68-3.70$ & 1.0 & 0.5 & 0.02 \\
\hline
\end{tabular}

The ANOVA result indicates that the levels of physico-chemical parameters in the three sampling points do not vary significantly with FEPA's and WHO's permissible limits for surface water $(\mathrm{F}=2.84$, $\mathrm{p}<0.05)$. Similarly, from the one way ANOVA, no significant differences at both temporal (f-ratio of 0.0017, p-value of 0.9983) and spatial dimensions (f-ratio of 0.0083 and p-value of 0.9917 ) for the nutri-chemical parameters at $\mathrm{p}<.05$ were recorded while t-test for comparing the mean concentration from the control also showed no significant differences $(\mathrm{p}<.05)$.

\section{CONCLusion}

The study for the determination of Nutri-chemical levels of the wastewater drains from vicinities around cement and associated factories in Port Harcourt, Nigeria revealed infinitesimal impact due to their direct operations but rather more impact from human activities around. The result showed that $\mathrm{pH}$, nitrates and sulphates were within regulatory limits (WHO, NSDWQ, FEPA, NESREA, USEPA, SON etc) but DO, phosphate and ammonia are much above allowable limits by these regulatory agencies which poses great danger to both ground water and water usage for other beneficial uses. It behooves on government to re-enforce her environmental monitoring and regulatory bodies to ensure compliance because of the gradual increase in the studied parameters.

\section{REFERENCES}

[1] Adekunle, A. S. (2008). Impacts of Industrial Effluent on Quality of Well Water within Asa Dam Industrial Estate, Ilorin Nigeria. Nature and Science, 6(3):1-5.

[2] Adekunle, A. S. \& Eniola, I. T, K. (2008). Impact of Industrial Effluents on Quality of Segment of Asa River within an Industrial Estate in Ilorin, Nigeria. New York Science Journal, 1(1):17-21.

[3] Adeyeye, E.I. (1994). Determination of heavy metals in Illisha, Africana, associated Water, Soil Sediments from some fish ponds. Int. J. Environ. Stud., 45: 231-240.

[4] Akoto, O.,Bruce, T.N. \& Darko, G. (2008). Heavy metals pollution profiles in streams serving the

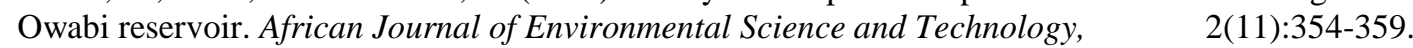

[5] Alemu, Z.A., Teklu, K.T., Alemayehu, T.A., Balcha, K.H. \& Mengesha, S.D.(2015). "Physicochemical quality of drinking water sources in Ethiopia and its health impact: a retrospective study". Environmental Systems Research, 4 (1): 22-32.

[6] APHA (1995). American Public Health Association. Standard methods for the examination of water and wastewater. American Public Health Association, Washington, DC American Public Health Association, American Water Works Association, and Water Pollution Control Federation, 1998, Standard methods for the analysis of water and wastewater $18^{\text {th }} \mathrm{Ed} ., 1998 ; 48-58$.

[7] APHA (1998). American Public Health Association. Standard Methods for the Examination of Water and Wastewater, Washington, DC, USA, 20th edition.

[8] Asaolu, S. S., Ipinmoroti, K. O., Adeeyinwo C. E. \& Olaofe O. (1997). Interrelationship of Heavy Metal Contamination in Water, Sediment a Fish of Ondo State Coastal Water. Journal of Science, 1: 55-60. 
[9] Bach Son Long, N.H., Gál, R. \& Buňka, F. (2011). Use of phosphates in meat products. African Journal of Biotechnology, 10 (86):19874-19882.

[10] Chien, S.H., Prochnow, L.I. \& Cantarella, H. (2009). "Recent developments of fertilizer production and use to improve nutrient efficiency and minimize environmental impacts," Advances in Agronomy, 102: $267-322$.

[11] Chukwu O. (2008). Analysis of Groundwater Pollution from Abattoir Waste in Minna, Nigeria.Research Journal of Diary Science, 2(4):74-77.

[12] Dimowo, B.O. (2013). Assessment of Some Physico-Chemical Parameters of River Ogun (Abeokuta, Ogun State, Southwestern Nigeria) in Comparison with National and International Standards. International Journal of Aquaculture, 3(15):79-84. http://ija.sophiapublisher.com

[13]DPR/EGASPIN (2002). Department of Petroleum Resources/ Environmental Guidelines and Standards for the Petroleum Industry. Environmental Guidelines and Standards for the Petroleum Industry in Nigeria. Revised Edition, Department of Petroleum Resources, Lagos.

[14] Duressa, G., Assefa, F. \& Jida, M. (2019). Assessment of bacteriological and physicochemical quality of drinking water from source to household tap connection in Nekemte, Oromia, Ethiopia. Journal of Environmental and Public Health, Volume 2019 |Article ID 2129792 |7pages | https://doi.org/ $10.1155 / 2019 / 2129792$.

[15]Ellila, M. (2011). The Use of Barium Sulphate in Printing Inks as Filler Material, Bachelor of Engineering Thesis, Helsinki Metropolia University of Applied Sciences, Helsinki, Finland.

[16] Ephraim, B. E. \& Ajayi, I. O. (2015). Compositional evaluation and quality status of surface waters of Mbat- Abiati and Oberekkai Creeks of the Great Kwa River, Southeastern Nigeria. Advances in Applied Science Research, 6 (6): 36-46.

[17] Ewa, E. E., Iwara, A. I., Adeyemi, J. A., Eja, E. I., Ajake, A. O. \& Otu, C. A. (2011). Impact of Industrial Activities on Water Quality of Omoku Creek. Sacha Journal of Environmental Studies, 1(2):8-16.

[18] Fakayode, S. O. (2005) Impact of Industrial Effluent on Water Quality of Receiving Alaro River in Ibadan, Nigeria. AJEAM-RAGEE, 10: 1-3.

[19]FEPA (1991). Federal Environmental Protection Agency. Guideline and Standard for Environmental Pollution Control in Nigeria.

[20] FMENV (2002). Federal Ministry of Environment. "National Guidelines and Standards for Water Quality in Nigeria", Abuja, Nigeria.

[21]GoN (2012). Rajpatra. Available at: http:// moste.gov.np/legal_documents/ Regulation?page=2\#. WMeUtNKGNdh.

[22] Habermeyer, P. \& Sanchez, A. (2005). Optimization of the Intermittent Aeration in a Full-Scale Wastewater Treatment Plant Biological Reactor for Nitrogen Control. Water Environ. Res., 77: 229- 233.

[23] Iyama, W. A. \& Edori, O. S. (2014). Analysis of the Water Quality of Imonite Creek in Ndoni, Rivers State, Nigeria. IOSR Journal of Applied Chemistry,7(11): 06-09. DOI: 10.9790/5736-07120609

[24] Iyama, W. A., Waribo, H. A. \& Okpara, K. (2016). Assessment of Nutrient and Biology Status of Bassan River Water in Bayelsa State, Nigeria. Advances in Agriculture and Biology, 5 (3):76-81.

[25] Iyama, W. A., Brown, H. \& Okpara, K. (2018). Introduction to Environmental Toxicology and Pollution Studies. Port Harcourt, Obisco Nig., ISBN: 978-1-79789-180-5.

[26] Joshi, D.M., Kumar, A. \& Agrawal, N. (2009). Studies on physicochemical parameters to assess the water quality of river ganga for drinking purpose in Haridwar district. Rasayan Journal of Chemistry 2(1):195-203.

[27] Morrison, G. O., Fatoki, O.S. \& Ekberg, A. (2001). Assessment of the impact of Point Source Pollution from the Keiskammahoek Sewage Treatment Plant on the Keiskamma River. Water SA, 27: 475-480.

[28] Muhammed, A.U., Nicolas, G. \& Joachim, V.B. (2016). The Impact of Drinking Water Quality and Sanitation Behavior on Child Health: Evidence from Rural Ethiopia, Center for Development Research, Bonn, Germany, 2016, ZEF-Discussion Papers on Development Policy No. 221.

[29] NDWQS (2005). National Drinking Water Quality Standards. Ministry of Physical Planning and Works, "National Drinking Water Quality Standards, 2005 Implementation Directives for National Drinking Water Quality Standards,” GoN, http://mowss.gov.np/assets/uploads/files/NDWQS_2005_Nepal.pdf.

[30] NSDWQ (2008). Nigeria Standard for Drinking Water Quality, Nigeria Industrial Standard, Approved by Standard Organization of Nigeria Governing Council. ICS 13. 060. 20: 15- 19.

[31] NESREA (2011). National Environmental Standards and Regulations Enforcement Agency Surface Water and Ground Water Quality Control) Regulations, 2011 (S.I. 22 of 2011). 
[32] Ogedengbe, K. \& Akinbile, C. O. (2004). Impact of industrial pollutants on quality of ground and Surface Waters at Oluyole Industrial Estate, Ibadan, Nigeria. Nigeria Journal of Technological Development, 4(2): 139-144.

[33] Ojekunle I. A. (2000). Transport and Urban Environmental Quality in Nigeria in Contemporary to AD 2000. Frankad Publishers, Lagos

[34] Patoczka, J. \& Wilson, D.J. (1984). Kinetics of the Desorption of Ammonia from Water by Diffused Aeration. Separation Sci. Tech., 19:73-93.

[35] Raj, J.A. \& Sevarkodiyone, S. P. (2018). A study on physico-chemical parameters of Urinjikulam Pond, Thiruthangal (Virudhunagar District, Tamil Nadu). Int J Aquac Fish $\quad$ Sci 4(1): 010-012. $\quad$ DOI: $10.17352 / 2455-8400.000036$

[36] Simpi B., Hiremath S. M., Murthy, K. N. S., Chandrashekarappa, K. N., Anil, N. P. \& Puttiah, E. T. (2011). Analysis of Water Quality Using Physicochemical Parameters Hosahalli Tank in Shimoga District, Karnataka, India. Global Journal of Science Frontier, $\quad$ Research, 1(3): 31-34.

[37] SON (2007). Standards Organization of Nigeria. Nigerian Standard for Drinking Water Quality, NIS 554, ICS 13.060.20: 30p

[38] Tesfamariam, Z. \& Younis, Y.M.H. (2016). Assessment of physicochemical parameters and levels of heavy metals concentrations in drinking water of Asmara city, Eritrea III. American Journal of Research Communication, 4(8):30-44. www.usa-journals.com

[39] Troyer, N. D., Mereta, S.T., Goethals, P.L.M. \& Boets, P. (2016). "Water quality assessment of streams and wetlands in a fast-growing East African city". Water, 8(4):123-144 Volume 2019 |Article ID 2129792 | https://doi.org/10.1155/2019/2129792-

[40] Uba, B.N. (1995). Nutrient status of wastewater in a fertilizer-factory-waste discharge equalization basin. Bioresource Technology, 51(2-3): 135-142.

[41] Ugbaja, A.N. \& Ephraim, B. E. (2019). Physicochemical and bacteriological parameters of surface water quality in part of Oban Massif, Nigeria. Global Journal of Geological Sciences 17:13-24. https://dx.doi.org/10.4314/gjgs.v17i1.2

[42] UN (2015). United Nations. Transforming Our World: the 2030 Agenda for Sustainable Development, UN, New York, NY, USA. https://sustainabledevelopment.un.org/post2015/transformingourworld.

[43] USEPA (1986). U. S. Environmental Protection Agency, Office of Water, 1986, Quality Criteria for Water (Gold Book), EPA 440/5-86-001, Washington D.C

[44] vlab.amrita.edu. (2012). Determination of pH of Waste Water Sample. Retrieved 5 September 2020, from vlab.amrita.edu/?sub=3\&brch=272\&sim $=1414 \& \mathrm{cnt}=1$.

[45] Walsh, G. E. (1980). Toxic Effects of Pollutants on Plankton; Environmental research laboratory, United State sEnvironmental Protection Agency, Gulfbreeze, Florida,32561, U.S.A,http://dge.stanford.edu/SCOPE/ SCOPE_12/SCOPE_12_3.6_chapter12_257- 274.pdf

[46] Wankhade, V., Manwar, N. \& Malu, A. (2012). Evaluation of status of ecosystem of Sawanga (Vithoba) Lake (Malkhed Talav), District Amravati, Maharashtra by assessment of Some Physicochemical

Characteristics of water. International Journal of Scientific and Research Publications, 2: 1-10. Link: https://goo.gl/WYWTXY

[47] WHO (1999). World Health Organization. International standard for drinking water, 5:3-6.

[48] WHO (2004). World Health Organization. Guidelines for Drinking Water Quality. Vol.1 Geneva, Switzerland (3rdEdition).

[49] WHO/UNICEF (2009). World Health Organization/ United Nations Children's Fund. Diarrhoea: Why Children are Still Dying and What Can Be Done, (WHO) and (UNICEF), Geneva, Switzerland.

[50]WRC (2014). Water Research Center, Phosphates in the Environment. http://www.waterresearch.net/index.php/phosphates.

Citation: Edori, Onisogen Simeon, et.al., “Assessment of Nutri-Chemical Concentration Levels of Wastewater from Drains Adjacent Cement and Associated Factories in Port Harcourt, Nigeria", International Journal of Research in Environmental Science (IJRES), vol. 7, no. 1, pp. 20-29, 2021. Available: DOI: http://dx.doi.org/ $10.20431 / 2454-9444.0701003$

Copyright: (C) 2021 Authors. This is an open-access article distributed under the terms of the Creative Commons Attribution License, which permits unrestricted use, distribution, and reproduction in any medium, provided the original author and source are credited. 